\title{
Video Recording to Reflect the Speaking Performance
}

\author{
Dian Rahma Santoso \\ Fakultas Keguruan dan Ilmu Pendidikan \\ Universitas Muhammadiyah Sidoarjo \\ J1. Mojopahit 666 B Sidoarjo, Indonesia \\ dianrahma24@umsida.ac.id
}

\author{
Wahyu Taufiq \\ Fakultas Keguruan dan Ilmu Pendidikan \\ Universitas Muhammadiyah Sidoarjo \\ J1. Mojopahit 666 B Sidoarjo, Indonesia \\ taufiq@umsida.ac.id
}

\begin{abstract}
This study aims to increase the students' confidence in delivering speech by recording their speaking performance. Students in this research have problems in performing speaking confidently, they always look nervous and unprepared unless they have made good preparation they write on a long script. This study investigates wether the video recording can arise the students' confidence in performing one minute speaking. This study used a descriptive qualitative approach by video-recording the students' performance, then synthesize, summarize and inteprete. The result showed that all of the students could increase their confidence through reflecting their own performance from the performance they had already recorded. The reflection is seen from the changing of speaking behavior. The students could perform with better and appropriate gestures, smiles, and expression at the next performance. They could also develop their performance without looking at the whole script but only the outline. The video such reflects the students' performance that made their confidence increased significantly. The implication of this finding helps the students to perform not only in speaking lecture, but also others which allow them to use their spoken activities.
\end{abstract}

Keywords—confidence; video recording; reflection; speaking

\section{INTRODUCTION}

Having good speaking ability according to Kransch, in O'Malley and Pierce, is advantagoeus to do negotiation the intended meanings and to produce the desired effect on the listener.[1] As an extensive or monolog activity, Brown said that speaking involves speeches, oral presentations, and storytelling, which listeners cannot put themselves in doing interaction with the speakers. [2]

The two theories in the opening pragraph above indicate that speaking is challenging because it combines the use of languange and speaking skill to give effect on the audience. In other words, Luoma says that speaking ability means reflecting spoken performance in foreign language from our personality, self-image, knowledge, and ability to reason end express thought. [3]

Speaking in front of public somehow makes many English learners nervous. They spent years to memorize vocabulary
[4], learn rules of grammar [5], practice pronouncing words [6], and developing semantic and syntactic competences [7], but they still found problems at performing in front of public. Difficulties in developing ideas because of less confident performance made the condition poorer [8].

This common condition is also faced by the researcher in teaching the third semester students of English Education Study Program, Faculty of Teacher Training and Education. The previous research had shown significant improvement of students' way of delivering good content of the opening speech. The result showed that all students could present their one minute opening speech clearly, state thesis statement speech preview. [9]

On the contrary, the improvement of delivering the opening speech was not balance when delivering the whole content of the speech. Most students tended to read script at the entire speech, and their eyes looked down on their pieces of paper. For other students who did not look at the script, they memorize every single thing on the script. In short, students cannot go away from the script.

Looking at this behavior, the researcher continued making video of their performance by expecting that the video could be evaluated together in front of the class. In other words, in terms of delivering the opening speech, the students had been able to present with good content delivery.

Several studies showed the relationship between confidence and speaking. The students felt lack of confidence in using English to communicate in the classroom. It seems they need to communicate with native speakers first then they can improve their confidence. Because of this less confident condition, most of them cannot begin the interaction of speaking. [10].

In relation with increasing confidence toward speaking delivery, Doqaruni conducted a research about increasing promoting confidence in a foreign language classroom. The research showed the increase of the students' confidence after incorporating speaking activities in the class and collaborating with their peers. It seems that this study also has great potencies to help the teachers become autonomous. [11] 
Furthermore, Al-Darwish \& Taqi investigated the effect of confidence and experience. They found that the lack of confidence caused by the lack of experience and practice which made an enhancement in language mistakes. [12]

Furthermore, numerous researches discussed how video can be beneficial in language teaching to improve students' ability in doing verbal presentation. Instead of adding the speaking competence, video recording can reflect the students' performance so they can perform better.[13] Moreover, the existence of video recording nowadays can be applied posting live videos, uploading to social media.[14]

Balancing the learning process with the era of technology, the researcher continued using video recorded from the students' speaking performance. The video recording itself has proven its much contribution to education, in this case, as a tool of reflecting practice. Many benefits appear from the integration of using technology and face-to-face interaction. Therefore Guo suggested video cameras could represent a language learning resource worthy. [15]

In accordance with investigating the students' performance which is recorded, the researcher expects much to the students in order that they can watch their own speaking performance through the video, check their weaknesses in doing the opening speech, evaluate the weaknesses and plan to have better performance.

In other words, the researcher wanted to investigate how the video-recording could reflect the students' performance in delivering the one minute opening speech. Besides, the researcher wanted to know whether the students could perform confidently in delivering the whole speech.

\section{RESEARCH METHOD}

\section{A. Research Design}

As this research investigate how video recording could reflect the speaking performance and their confidence in delivering the speech, the research is designed with qualitative approach, telling the result of observation and test. The reseach population is the third semester students of English Education Study Program class A1 which consist of 24 students.

\section{B. Instrument, Data Collecting, and Data Analysis}

The techniques of collecting data obtained from the observation of the students' performance videos which are recorded by the classmates. To get the video, the students work in pair, just say, student A performs speaking and student B records the A's performance. Then, both of them switch their roles, student B performs speaking and student A records the B's performance. In doing performance recording, all students use their own smart phones to make them easy to evaluate their own performance. The researcher then put the observation report on filed note.
Besides, the researcher also collects the data by doing interview. This instrument is used to get the students' perspective about the implementation of recording their performance. The researcher wants to gain their perspective in what aspect the video recording can reflect their performance so they can increase confidence in performing opening one minute speech.

The theme used in the learning process is Education in Teaching English and the students can freely break down the theme into more specific topics they master or they like to discuss. The researcher expects the research will motivate the students to perform better every meetings, deliver the speech without looking at the script, but only a small note and by looking at the camera.

In analyzing the students' performance, the observation was used to give feedback. Last, the students watched their video together and get evaluation from either the researcher or students. Then, the way of analyzing the data is done by making synthesis, summary and interpretation.

\section{FINDING AND DISCUSSION}

\section{The Students' activity with video recording}

Generally, the activity of delivering one minute speech during the research was very challenging for students. They never realize that the first one minute must be spoken impressively because it can attract the auidence' attention to listen to the complete speech. Yet, as the researcher said before, this study investigates the students' performance by video recording to deliver the speech confidently.

\section{The First Performance}

The first day of the performance seemed horrible. It was difficult situation for students because they were not accustomed to looking at their own face talking to themselves in front of the camera. They did several minutes off before performing to take breath and make them calm. LBP just performed couple of seconds then she stopped, she took deep breath, smiling and laughing at herself, but they were very enthusiast looking at their own facial expression in front of the camera.

In addition, their facial expression also looked very nervous. It seemed that they could not neglect the nervous feeling since some of them looked at the ceiling, some others looked at the right or left side, some others looked at one person, her close friend, and focused on her to cover the nervousness. In this condition, the lecturer gave motivation to students to control the unimportant smiles and nervousness by taking deep breath several seconds before performing, having a cup of tea (if necessary), and speak outloud in a hidden place without disturbing other people.

Besides, the teacher emphasized to the students about feeling nervous. It was not because they cannot perform well, 
but it was the sign that they wanted to perform their best but they were afraid they perform unwell. The students then followed the lecturer's direction and ready to prepare the next performance.

The good thing is by looking a their performance, they finally realize if they need a lot of improvements in presenting the speech, in this case, one minute speech. So, they decided to look again and give more attention to the way they deliver the speech. This condition is assumed that the students thought and prepared the performance seriously.

This is in line with Brown's statement that speaking has some micro skills: 1) accomplishing communicative functions related to the situations, participants, and objectives; 2) conveying links and connection between events and communicate the ideas, events, feelings, new and given information, generalization and exemplification [2].

\section{The Second Performance}

The second performance looked different from the first one. The students used appropriate body language during the performance. They were not too nervous, although still nervous, looking at themselves in front of the camera. It shows that the previous video reflected their performance better. They also accepted the lecturer's suggestion in order to control the inappropriate smiles and nervousness.

Besides, their facial expression also looked less nervous. It showed that they could manage the nervous feeling. Some of them still looked at the right or left side but no students looked at the ceiling when performing the one minute speech in front of the camera.

This situation makes the researchers assumed that the students were serious and positive thinking toward the new things which can finally reflect their better performance. The students now believe that performance can be changed in accordance with the readiness and hard practice before performing. So they understood that every small thing cannot be underestimated. One minute speech is a small thing, but if it is unprepared, they can embarrace their own performance.

\section{The Third Performance}

Next, the students were more confident after practicing delivering the speech several times. They could control their behavior in front of the camera, they smiled nicely right in front of the camera. The researcher could see from the video they made that they could reduce much nerveousness. The students kept practicing the one minute speech until they found the best look in front of the camera.

Almost all of the students could deliver the speech well without looking at the script. So the lecturer showed through big screen the video of AA, LGF, DA, and LBP then discussed what was good and what was not good. The students wrote what the lecturer suggested. They drew some the points on a note as an outline, then practice before speaking in front of public. Comparing to those who were not confident, the students focused looking at the text or script they made. This way was not recommended because looking at the script could not make our brain to think harder or to be creative because they only relied their speakimg performance on their script memorization.

Although there were few students could not move away from their script memorization, video recording truly supported the learning process. It helped the students evaluate their own speaking performance which reflected to the influence of their way of thinking. Therefore, the researcher agreed toward Guo's statement that video recording could be one of the useful way to improve students' presentation with high quality visuals that had been perceived to improve their learning [15].

Besides, the video recording gave the students' learning experience in which it educates themselves to draw the speaking feedback each other verbally. As stated in the reseach method, the students used their personal smart phone to record their performance. There, a student recorded and then gave verbal evaluation to his/her pair and vise versa.

This condition helped them increase their confidence to express their idea about their pairs' strength and weakness' points on the speech delivered. This is then in line with the result of Devi and Krish's study which found that the video recording activity has proven to support themselves and peer feedback as well as empower the learners with positive learning experience. [16]

\section{Students' Perspective toward the video recording}

The students' preparation before performing one minute speech according to the interview with some students were excellent. They tried to make great opening or introductory speech which consist of introduction, thesis statement, and preview [17].

NSM believed that speaking with those organization helped her speak better and chronologic although she had not implemented completely as what the lecturer suggested yet. The video reflected her speaking performance that she needed to decrease nervousness that looked clear in the video. Furthermore, she understood what was correct and incorrect to make better introductory speech. The nice thing she expressed was that she could perform more confidently after paying attention to the video.

AA expressed that she was enthusiast looking at her performance through the video her friend had recorded. She enjoyed getting verbal comments from her friends about her performance. She then could use the comments to perform better and more confident.

HR also stated that she could finally focus her eyes to the camera after looking at her performance on the video. She realized if she was not confident enough when delivering the one minute speech. She needed a lot of improvements in presenting the speech confidently. She thought further when she got task to speak five to seven minutes one day, she was not sure she could perform well. But she believed that by listening to friend's comments, learning from the mistakes 
from the video, and doing hard practicing, she would be able make it.

DI stated when she saw her own face on the video, she knew that her performance was not good. She could not focus her face on the camera and could not smile appropriately during one presentation. She then evaluated herself from the video, she reflected what was missing in the performance, listened to the lecturer's suggestion, and she finally could perform better at the second chance, although not the best she could, but she kept practicing.

Those several perspective indicates that recorded performance helps the students analyze their own and their pair's speech. It can increase their motivation which impacts on the better confident performance. This also means that confidence is one of the factors that motivate students to increase communication by using English.

Therefore, it is true MacIntyre et al. once suggested that self-confidence contributes to the learner's willingness to communicate in a foreign language affected by factors such as motivation, personality, and intergroup climate [18].

In relation between confidence and the definition of speaking according to Kranch and Brown, confidence could increase the competence of extensive or monolog activity to interact [2] and negotiate the intended meaning (content) of the speech so it brings the desired effect on the listener to do some actions as what the speaker stated in the speech [1].

\section{CONCLUSION}

Confidence is not a gift or talent that comes to certain people, but it appears because of drilling, rehearsing, reflecting one to other performance. Performing three times one minute speech, in fact, could increase better and more confident speech delivery. The recorded video they had made and then watched could reflect their performance which made them evaluate their own performance.

Reflecting the performance from the video can increase the students' motivation which influence their confidentce so they can make better performance. In other words, the video has pulled out their confidence which gives them chance to communicate with people, express their idea by using English, or it might also other foreign languages.

The external factors such as friends' verbal comments, lecturer's suggestion and motivation become the important roles and unseparated parts in boosting the students' confidence to presents the one minute opening or introductory speech showed by the decrease of nervousness, the increase of content delivery added with appropriate gestures, smiles and eye contact.

Thus, presenting the one minute introductory speech confidently is one of the successful learning parameters in speaking class of the English Education study program. To other researchers, it is highly recommended to do further researches with other parameters such as how to increase speaking grammatically, and more fluently with excellent word choice.

\section{ACKNOWLEDGMENT}

I send my special gratitude to the third semester students of English Education Study Program who gave me inspiration in accordance with their participation so that I finally finish my paper. I also thank to my little family, husband and the three musketeers of my life who ..... finally I thank to Universitas Muhammadiyah Sidaorjo who gives me a chance to publish this article.

\section{REFERENCES}

[1] O’Malley, J. M. \& Pierce, L. V. (1996). Authentic Assessment for English Language Learners. Addison-Wesley Pub. Co.

[2] Brown, H. D. (2004). Language Assessment: Principles and Classroom Practices. White Plains, New York: Pearson Education.

[3] Luoma, S. (2004). Assessing Speaking. Cambridge University Press. http://dx.doi.org/10.1017/CBO9780511733017

[4] Efrizal, D. (2012). Improving Students' Speaking through Communicative Language Teaching Method at Mts Ja-alhaq, Sentot Ali Basa Islamic Boarding School of Bengkulu, Indonesia. International Journal of Humanities and Social Science, 2 (20): 127-132.

[5] Romero, B. N. (2015). Improving Speaking Skills. Encuerto, 18: 86-90.

[6] Wahyuni. (2012). Using Round Table Card Games to Improve Speaking Ability of Seventh Grade Students of SMP Negeri 3 Bangil 2012 in Describng Things and People. 1 (1): 58-62.

[7] Yunus, M. (2012). Improving Students' Speaking Skill through Guided Questions with Inside Outside Circle Technique. Language-Edu, 1 (1): 29-37.

[8] Doqaruni, V. R. (2015). Increasing Confidence to Decrease Reticence: A Language Qualitative Action Research in Second Language Education. Canadian Journal of Action Research, 16(2), 42-60.

[9] Santoso, D. (2017). Implementing Video Recording to Improve the Content of Opening Speech. Journal of English Educators Society, 2(1), 21-32. doi:http://dx.doi.org/10.21070/jees.v2i1.713

[10] Yashima, T., Zenuk-Nishide, L., \& Shimizu, K. (2004). The influence of attitude and affect on willingness to communicate and second language communication. Language Learning, 54(1), 119-152.

[11] Doqaruni, V.. 2015. A Quantitative Action Research on Promoting Confidence in a Foreign Language Classroom: Implications for Second Language Teachers. i.e.: inquiry in education, 5(1): 1-30. http://digitalcommons.nl.edu/ie/vol5/iss1/3

[12] Al-Darwish, S. H. \& Taqi, H. A. (2015). EFL PresentationsInvestigating The Effect of Confidence and Experience. International Journal of English Language Teaching, 3(1): 74-88.

[13] Kirkgoz, Y. (2011). A Blended Learning Study On Implementing Video Recorded Speaking Tasks In Task-Based Classroom Instruction. TOJET (The Turkish Online Journal of Education Technology), 10 (4): 1-13.

[14] Talanker, S. (2013). How Teachers Can Learn From Video-Recorded Lessons. Activity Report. Jerussalem: Initiative for Applied Education Research, The Israel Academy of Sciences and Humanities.

[15] Guo, R. X. (2013). The Use of Video Recordings as an Effective Tool to Improve Presentation Skills. Polyglossia, 24: 92-101.

[16] Devi, I. \& Krish, P. (2016). Video Recordings of Oral Presentations: A Neuroscience Intervention in ESP instruction. The Social Sciences 11(12): 2987-2994.

[17] Rybold, G. (2006). Speaking Listening and Understanding: Debate for Non-Native-English-Speaker. New York: International Debate Education Association. 
[18] Maclntyre, P. D., Clement, R., Dornyei, Z., \& Noels, K. A. (1998). Conceptualizing Willingness to Communicate in a L2: A Situational model of L2 confidence and Affiliation. Modern Language Journal, 82, 545-562. 